\title{
De/centralized Decision Making Under the European Resolution Framework: Does Meroni Hamper the Creation of a European Resolution Authority?
}

\author{
Pamela Lintner ${ }^{1}$
}

Published online: 14 October 2017

(C) The Author(s) 2017. This article is an open access publication

\begin{abstract}
The EU Bank Recovery and Resolution Directive (BRRD) shifts the focus from reacting in the face of a crisis, to planning and preparing to avoid uncoordinated, ad hoc measures and aims to ensure banks resolvability; it strengthens and harmonizes early intervention measures and gives supervisors new tools and powers for managing failing banks while continuing part of their business, i.e. critical functions. The BRRD was conceived out of a need to reduce public funds being used to bail out banks considered 'too big to fail' and strengthen cooperation and coordination between Member States. The first part of this paper sets out how key resolution decisions, including during recovery and resolution planning, are taken for cross-border banking groups within the EU, and within the Single Resolution Mechanism (SRM) of the euro area. It also considers the impact of the BRRD on cooperation with third countries (small host countries). The second part of the paper offers a legal analysis of why no autonomous centralized decisionmaking powers were delegated to the Single Resolution Board (SRB). It considers whether legal judgements made in 1956 and enshrined as the 'Meroni doctrine' actually prohibit delegation of fully autonomous resolution powers to the SRB and more broadly prevent the creation of a centralized resolution agency for the whole EU.
\end{abstract}

The second part of the article (Sect. 3) is based on the author's Dissertation The European Agencies in the Banking Sector: An analysis of their powers in light of [recent] case law on the example of the European Banking Authority (EBA) and the Single Resolution Board (SRB), written at the Johannes Kepler University Linz in 2015. The findings, interpretations and conclusions expressed are entirely those of the author; they do in no way represent the views of the International Bank for Reconstruction and Development/The World Bank and its affiliated organizations.

Pamela Lintner

plintner@worldbank.org

1 Sr. Financial Sector Specialist, Vienna Financial Sector Advisory Centre (FinSAC), Vienna, Austria 
Keywords Bank resolution - Bank Recovery and Resolution Directive (BRRD) · Banking Union · Single Resolution Board (SRB) · Meroni

'Ideally there would be a single pan-European authority that "would deliver a rapid, decisive and equitable resolution process for European financial groups, and better reflect the pan-EU nature of banking markets", 1

\section{Introduction}

The EU Bank Recovery and Resolution Directive (BRRD) translates the Financial Stability Board's Key Attributes of Effective Resolution Regimes for Financial Institutions (KA), endorsed by the G20 in 2011, into the EU context. It shifts the focus from reacting in the face of a crisis, to planning and preparing to avoid uncoordinated and ad hoc measures, and aims to ensure banks' resolvability; it strengthens and harmonizes early intervention measures to address problems before they escalate; and it gives supervisors new tools and powers to manage a failing bank while continuing its critical economic functions. The BRRD was conceived out of a need to reduce public funds being used to bail out banks considered 'too big to fail' and strengthen cooperation and coordination between Member States to ensure that actions are applied in a coherent manner across different jurisdictions. This new regime has significance too for countries outside the EU, particularly where cross-border banking groups of EU parent companies are present.

The first part of this paper (Sect. 2) sets out how key resolution decisions, including during recovery and resolution planning, are taken for cross-border banking groups within the EU, and within the Single Resolution Mechanism (SRM) of the euro area. ${ }^{2}$ It also considers the impact of the BRRD on cooperation with third countries (host countries), and the inherent challenges and possible effects on these relationships. Cross border resolution under the BRRD fundamentally relies on consensus and cooperation both on the vertical level between the European institutions and national authorities as well as on the horizontal level between Member States. If joint decisions on cross-border groups cannot be reached, then the responsibility in most cases reverts to individual national resolution authorities rather than to a central enforcement body. Within the euro area, the SRB takes a centralized decision on resolution planning and the application of resolution tools. However also within the SRM, national authorities must agree on the basis of majority votes and the European Commission and Council of the EU are empowered to exercise veto rights over the SRB's resolution decisions.

The second part of the paper (Sect. 3) offers a legal analysis of why no autonomous centralized decision-making powers were delegated to the Single Resolution Board (SRB). It provides a critical analysis of the so called 'Meroni doctrine' which dates back to a legal judgements made in 1956 on the delegation of

\footnotetext{
1 Alford (2013), pp. 244, 257.

${ }^{2}$ For an overall analysis on the EU post-crisis administrative machinery within the internal market of financial services and EMU, see, for example, Chiti (2015), pp. 311-333.
} 
regulatory powers by the EU Commission (back then High Authority) to a (private) agency in the area of competition. This ruling is still used as an argument for limiting the extent of delegation by the legislative authorities-Parliament and Council-to Agencies created under EU law also outside the area of competition, where the Commission does not ex Treaty possess specific implementing powers but is limited by Member States control (comitology arrangements). It is discussed under which conditions a delegation of resolution powers to the SRB without Commission and Council veto rights could legally be justified, and more broadly even provide for the creation of a centralized resolution agency for the whole EU.

\section{Cross-Border Cooperation Under the BRRD and Centralization Under the SRM}

Under the BRRD, each National Resolution Authority (NRA) is, in principle, responsible within its jurisdiction for taking necessary actions (key resolution actions are described in detail below). Automatic recognition of resolution decisions within the EU, including bail-in, is stipulated in law. In parallel to supervisory colleges, the establishment of resolution colleges is foreseen to facilitate cooperation and joint decision making at all stages of resolution, from resolution planning to the implementation of cross-border resolution action. The BRRD defines the following criteria for College membership: the resolution authority of the parent and of each subsidiary and significant branches; the relevant supervisory authorities (possibly accompanied by the central bank), the competent ministries; deposit guarantee schemes (DGS); and the European Banking Authority (EBA).

For euro area countries, bank resolution is centralized under the SRB stipulating, however, for a wide scope of veto powers for the Commission and the Council. The SRB acts as home authority for the entities under its remit ${ }^{3}$ and decides on the application of resolution tools and the use of the Single Resolution Fund (SRF) financed by the banking industry. The SRB, made up of NRAs as its constituent members, applies its own tools and powers under the SRM regulation (and not only the BRRD as transposed by Member States). ${ }^{4}$ Its decisions are directed towards NRAs for their enforcement under national legislation transposing the BRRD and national insolvency law if required. Only exceptionally, if NRAs fail to comply with the SRB's decisions, may the SRB execute resolution action directly.

Regarding cooperation with third countries, i.e. non-EU jurisdictions, the BRRD foresees three principle methods:

(i) Cooperation and information sharing in resolution colleges. Third country authorities may request to join, as observers, the college where an EU

\footnotetext{
3 All significant banks that come under the direct supervision of the ECB, plus cross border banks, as well as any resolution case that requires the use of the Single Resolution Fund (SRF), come under the SRBs remit. See, for a list, https://srb.europa.eu/en/node/44 (accessed 24 April 2017).

${ }^{4}$ Government Stabilization tools as foreseen under the BRRD (in the form of temporary public ownership or public recapitalization) are not available to the SRB but remain to be decided at the national level.
} 
parent has a significant subsidiary or a significant branch in the third country on condition that confidentiality requirements are the same. ${ }^{5}$

(ii) Cooperation agreements. The EBA may conclude non-binding cooperation and information sharing framework arrangements with 'relevant' third country authorities. Based on these, individual NRAS make non-binding arrangements which may include provisions on, for example: information exchange necessary to prepare resolution plans and exercise resolution powers/tools under the law of a third country; cooperation and coordination to prepare resolution plans; cooperation arrangements before taking any resolution action (early warning); coordination of public communication in case of joint resolution action (including through crisis management groups for global systemically important banks (G-SIBS).

(iii) Recognition and enforcement of third country resolution decisions. It is left to individual Member State resolution authorities and/or colleges to decide if third country decisions are recognized (see in detail below Sects. 2.2.1, 2.2.3 and 2.3.3).

\subsection{Decisions During Recovery and Resolution Planning}

\subsubsection{Arrangements Under the BRRD}

The BRRD establishes a harmonized regulatory framework to facilitate the adoption of recovery and resolution plans as well as the provision of intra-group financial support in the EU.

Among EU Member States, the objective of cross border banking groups' recovery and resolution plans must include the stabilization of the group as a whole covering all (material) entities in a holistic way. Coordination is required via resolution colleges. A group recovery plan ${ }^{6}$ is drawn up by the parent undertaking and submitted to the consolidating supervisor. In principle, all subsidiaries (plus any significant branches) are included in the group recovery plan. ${ }^{7}$ Additional individual plans are only needed if required by the supervisor of the subsidiary. Article 8(4) stipulates for a joint decision on the question if an individual plan is to be drawn up. If no joint decision can be reached each resolution authority takes its own decision and may request individual plans. ${ }^{8}$ Binding EBA mediation for group recovery

\footnotetext{
5 Art. 88(3) BRRD, Directive 2014/59/EU of the European Parliament and of the Council of 15 May 2014 establishing a framework for the recovery and resolution of credit institutions and investment firms.

${ }^{6}$ Recovery plans are drawn up by credit institutions and lay out measures that can be executed in the event of a deterioration of their financial situation aiming to restore their viability.

7 EBA RTS on the content of recovery plans list six key criteria for the inclusion of entities in group recovery plans depending of their 'materiality'. Critical functions under resolution and resolution tools can only be applied to legal entities. Hence the identification and segregation of material legal entities (MLEs) is key for the application of resolution tools.

${ }^{8}$ Art. 8 para. 4 BRRD. Competent authorities that do not disagree may reach a joint decision on the group recovery plan for their entities. The wording in Art. 8 para. 7 seems to exclude the question of 'group vs individual plan' from EBA mediation.
} 
plans is only provided for measures to direct the parent and/or the subsidiary to reduce risk profile, enable recapitalization, and to change funding strategy. ${ }^{9}$ No statutory binding EBA mediation is stipulated on the question of group vs individual plan. ${ }^{10}$ In practice, it will depend on how and in what depth subsidiaries are covered in group recovery plans if the national resolution authorities are satisfied or they see a need for an individual plan from their subsidiary to protect their national economic and financial stability interests.

Resolution authorities are expected to reach a joint decision for the adoption of a group resolution plan and resolvability assessment including the removal of impediments to resolvability by requiring changes to the legal or operational structure of a bank. A draft group resolution plan and resolvability assessment is circulated by the parent resolution authority in the college. In the absence of a joint decision, ${ }^{11}$ the parent authority will adopt its own group level resolution plan and each subsidiary resolution authority will adopt an entity resolution plan and resolvability assessment ${ }^{12}$ including any measures to address and remove impediments to resolvability. ${ }^{13}$ Individual plans have to be shared with the group level resolution authority. ${ }^{14}$ Any resolution authority may refer a decision by another resolution authority (at consolidated level, of the parent or another subsidiary) on resolution plans to the EBA for binding mediation. EBA mediation defers decision taking from the respective authorities, and requires them to follow the EBA's decision. However, if a resolution authority argues that the subject matter under disagreement may impinge on its 'fiscal responsibilities' the issue is excluded from EBA mediation and the subsidiary resolution authority can go ahead with its own national resolution plan. Compared to recovery plans, national resolution authorities are given less leeway to adopt individual resolution plans in case of disagreement and are as a rule bound by EBA mediation.

In parallel, and as part of the resolution planning process, the BRRD requires authorities to set minimum requirements for eligible liabilities (MREL) for each institution at the individual and at a consolidated level. MREL aims to ensure that each entity is able to absorb losses and can be recapitalized with high quality instruments without causing contagion and risk to financial stability. ${ }^{15}$ The BRRD leaves it to the resolution authority to decide on the resolution strategy (single point

\footnotetext{
9 Art. 8(7) BRRD.

10 The wording in Art. 8 para. 7 seems to exclude the question of 'group vs individual plan' from EBA mediation.

11 Both must set out the reasons for disagreement with the proposed group resolution plan, and other resolution authorities can go ahead with the group resolution plan, even if some subsidiaries choose to adopt their own entity resolution plan.

12 This requires consultation with the consolidating supervisor and the competent authorities of the subsidiaries, as well as with the resolution authorities of the jurisdictions in which significant branches are located, insofar as is relevant to the significant branch (Art. 16).

13 In accordance with Art. 17 BRRD.

14 Art. 74 Commission Delegated Regulation (EU) 2016/1075.

15 Liabilities governed by the law of a third country do not count as MREL, unless the EU resolution authority is fully satisfied that its decision to bail in this instrument would be upheld under the law of the third country.
} 
of entry (SPE) or multiple point of entry (MPE)) and does not set any internal arrangements regarding loss-absorbing capacity. Currently, it is not specified whether loss-absorbing instruments can be internal, i.e. from within the banking group, or must be external, i.e. issued on the market. The parent resolution authority will submit a proposal to set MREL for the parent and at consolidated level, while the host resolution authorities propose MREL at subsidiary level. The parent then drafts a joint decision, setting MREL at consolidated, parent and each subsidiary level. With the agreement of the host, the individual requirement for a subsidiary can be waived. If no joint decision can be reached for MREL at consolidated and parent level the group resolution authority will take its own decision and communicate it to the college; all the resolution authorities should still strive to reach a joint decision to set MREL for each subsidiary together. In the absence of a joint decision (also) on the individual MRELs, each resolution authority takes its own decision which is communicated to the college. No EBA involvement is stipulated.

If group entities apply for authorization of an intra group financial support agreement (IGFSA), ${ }^{16}$ supervisors of each entity of the group have 4 months to review the agreement and reach a joint decision. If no consensus can be reached, the consolidating supervisor (the ECB within the euro area) will make its own decision, taking the views and reservations of the other competent authorities into account. If one of the other supervisors refers the matter to EBA, it must take a decision within 1 month, which is then binding on the group level supervisor. Following authorization by the competent authorities, the shareholders of every group entity that proposes to enter the agreement need to approve the agreement and authorize their management to provide/receive support if required. In the event that support based on an IGFSA is actually requested, the competent authorities have to decide to agree, prohibit or restrict the proposed support within 5 days. EBA may only be asked for non-binding assistance but the final decision on whether support is provided or not always remains with the supervisory authority of the providing entity.

\subsubsection{Arrangements in the Euro Area Under the Single Supervisory Mechanism (SSM) and the Single Resolution Mechanism (SRM)}

For euro area banks under the direct remit of the ECB (Single Supervisory Mechanism/SSM) and the SRB (Single Resolution Mechanism/SRM), the distinction between home and host authorities is dissolved. The institution responsible for the assessment of recovery plans for the respective parts of the group under the ECB's direct remit is the ECB, in consultation with the SRB and/or NRAs. ${ }^{17}$ Similarly, for the phase preparing for when a bank actually enters into resolution, group resolution plans including resolvability assessment and the setting of loss

\footnotetext{
16 This support can be between EU Member States and between EU Member States and the SRB. Group entities in third countries may be part of an IGFSA if the authorities agree.

17 Credit institutions' recovery plans are analysed and assessed by the Joint supervisory teams (JSTs) supported by the ECBs Crisis Management Division. See ECB Guide to banking supervision, November 2014.
} 
absorbing capacity (MREL) are decided by the SRB in its 'extended' executive session. ${ }^{18}$ National (political) bargaining at this important stage of predefining possible use of resolution tools is widely excluded, as in the SRBs executive session only the four permanent members and the Chair decide on the adoption of resolution plans if no consensus can be reached. ${ }^{19}$ If the group also includes entities of nonparticipating EU Member States, the plans for the EU group entities are discussed in Resolution Colleges where the SRB with the other resolution authorities for the whole group should aim to reach and agree a joint decision (see above Sect. 2.1.1). ${ }^{20}$

\subsubsection{Participation of Third Countries}

The BRRD provides a broad framework for cooperation for cross-border crisis prevention and crisis management arrangements, but remains vague on the level and content of information exchange. Cooperation and coordination with third country authorities will depend on whether the host entity will be 'material' enough to be in the College or if a bilateral arrangement is agreed. With the definition of 'material importance', questions arise on the inclusion of third countries in supervisory and resolution colleges. It is also not clear to what extent information will be shared with observers and if with all observers the same, e.g. whether the whole group recovery and resolution plans or only certain parts should be made available to all or only some third country host authorities. Group entities of third countries can and should be part of a group recovery plan (holistic approach). Entities that could not be disposed or liquidated without triggering a major risk for the group are to be included; EBA refers to the importance of a legal entity to the financial stability of (only) a EU Member State. ${ }^{21}$ Third country group entities are obviously not part of the EU group resolution plan as regards the application of tools and powers (this would be outside their jurisdiction). EU resolution authorities are, however, held to identify arrangements for cooperation and coordination with the relevant authorities of entities located in third countries in the resolution plan. Also group entities in third countries will be part of resolvability planning, for example regarding the provision of critical functions in other jurisdictions. The EU resolution authority's choice of resolution strategy will impact third county entities. Though, so far, not formally foreseen under the EU resolution framework, the decision of an SPE or an MPE approach will fundamentally impact banks' organizational and structural setup in the going concern, thereby determining the mid- to long-term structure of the banking sector and also affecting subsidiaries of EU banking groups in third

\footnotetext{
18 The extended executive session incudes the respective national resolution authorities of the relevant bank in addition to the restricted executive session Members i.e. SRB Chair, four board Members, vice chair, Observers: ECB, EC, EBA (where relevant for L2 legislation). There is no Commission or Council involvement (Veto rights).

19 Art. 55 SRMR (Reg. 806/2014).

20 The resulting SRB report on the resolvability assessment is provided to the resolution authorities of non-participating EU Member States with significant branches (but not to subsidiaries, because they are in the college anyway).

21 EBA/RTS/2014/11.
} 
countries. Often small host countries that may be significant in terms of the local market but small relative to the parent bank's operations.

\subsection{Decision When Taking Resolution Action and Applying Tools and Powers}

\subsubsection{Arrangements Under the BRRD}

Under the BRRD each resolution authority is, in principle, responsible for the entity under its jurisdiction and takes an individual decision on whether to start the resolution process or not and which resolution tools to apply. ${ }^{22}$ Resolution action in one jurisdiction could impact other parts of a group, with the result that they may also be likely to fulfill the conditions for taking resolution action. In this case, within 24 hours of receiving notice from the national resolution authority of impending resolution action, the group level resolution authority must decide on and share a group resolution scheme with all college members. A group resolution scheme outlines the resolution actions to be taken by the relevant national resolution authorities (the SRB) in relation to the group parent and/or specific group entities. A group resolution plan will normally have been reached ex ante (but not necessarily, see above Sect. 2.1). Ideally also a common understanding on burden sharing arrangements and a financing plan will already be in place (as part of the resolution plan). There is no (legal) certainty provided under the BRRD that a group resolution plan will be enacted as foreseen or that a common cross border resolution strategy will be applied. Cooperation in the college is stipulated when either a subsidiary or when a group parent company meets the conditions for resolution. The EBA may assist in reaching a joint decision on the group resolution strategy (but no binding mediation is stipulated). Each resolution authority may take its own decision for reasons of financial stability, although it is obliged to provide a detailed reasoning. Resolution authorities which reach a joint decision may obviously go ahead in unison for the parts of the group under their respective jurisdictions. ${ }^{23}$

The BRRD requires EU Member States to recognize and enforce measures taken by the resolution authorities of other Member States. It gives priority to the home Member State regarding branches and thereby excludes the possibility of multiple resolution proceedings in branch Member States, i.e. the home decides what happens with all branches throughout other MSs. ${ }^{24}$ The home resolution authority has powers to suspend termination rights and impose temporary stays; and to override netting and repurchase agreements governed by the laws of other Member

\footnotetext{
22 Note that also an EU branch of a group with the parent in a 3rd country can be put into resolution by an EU RA if the RA of the 3rd country does not cooperate and if the EU RA decides this is necessary and in the public interest (Art. 96).

23 Arts. 91 and 92 BRRD.

24 This was already the case in the winding up Directive 2001/24/EC which ensures the mutual recognition within the EU of reorganization measures and winding-up proceedings. See also Art. 117 of the BRRD which amends, inter alia, the definition of 'reorganization measures' set out in Art. 2 of Directive 2001/24 to include the application of the resolution tools and the exercise of resolution powers provided for in Directive 2014/59/EU.
} 
States. Hence, within the EU, the transfer of a property located in another Member State can be perfected and ensures effective cross border resolution. This is obviously more difficult in third countries.

\subsubsection{Arrangements in the Euro Area under the Single Supervisory Mechanism $(S S M) / S R M$}

For euro area Member States within the SRM, the ECB normally triggers the decision if an institution under its direct supervision is considered failing or likely to fail (FOLTF). The SRB may exceptionally also determine that a bank is considered FOLTF if it has informed the ECB of its intention to do so and the ECB has not reacted within 3 days. ${ }^{25}$ The SRB decides first if the conditions for taking resolution action are fulfilled (the European Commission and the Council of the European Union have no powers in this regard) and second on the application of a resolution strategy (possible blocking minority within the SRB). ${ }^{26}$ If the SRB makes an initial positive determination that resolution is in the public interest the European Commission and the Council have power to veto approval of the SRB's resolution strategy. The SRBs proposal is transmitted to the Commission, which can, within 24 hours, either endorse the resolution scheme, object to it, and/or amend it 'with regard to the discretionary aspects of the resolution scheme'. The Council's involvement depends on the Commission's proposal to act and it may object to or approve the SRB Boards positive assessment on public interest and/or the use of the Resolution Fund. In case of an objection, the SRB has 8 hours to modify the resolution scheme. If the Council objects because it considers taking resolution action not to be justified in the public interest, the procedure is stopped and the entity wound down under regular national insolvency procedure. If there are no objections, the resolution scheme enters into force (see Fig. 1 for an outline of the decision-making process under the SRM).

Once approved, the implementation phase starts. The local national resolution authorities are responsible for implementing the tools set out by the resolution scheme. A proper and comprehensive transposition of the BRRD into national law is key to enabling local authorities to act with full powers and ensure coherent application of resolution tools. ${ }^{27}$

\footnotetext{
25 Art. 18 SRMR.

26 The scheme is, as a rule, adopted by the executive session: if no consensus between the NRAs concerned can be reached as the final voting takes place between the four permanent members plus the Chair, according to the principle one member one vote. Only if triggered by an NRA and if the calculated amount drained from the SRF for the financing of the respective resolution action is more than 5 bn, the plenary session will decide: the voting process gives room for political bargaining insofar as a minimum of $30 \%$ of the resources in the SRF has to be reached. Art. 52, Regulation 806/2014.

27 The no creditor worse off than under liquidation (NCWOL) test, for example, is based on the respective national insolvency laws.
} 


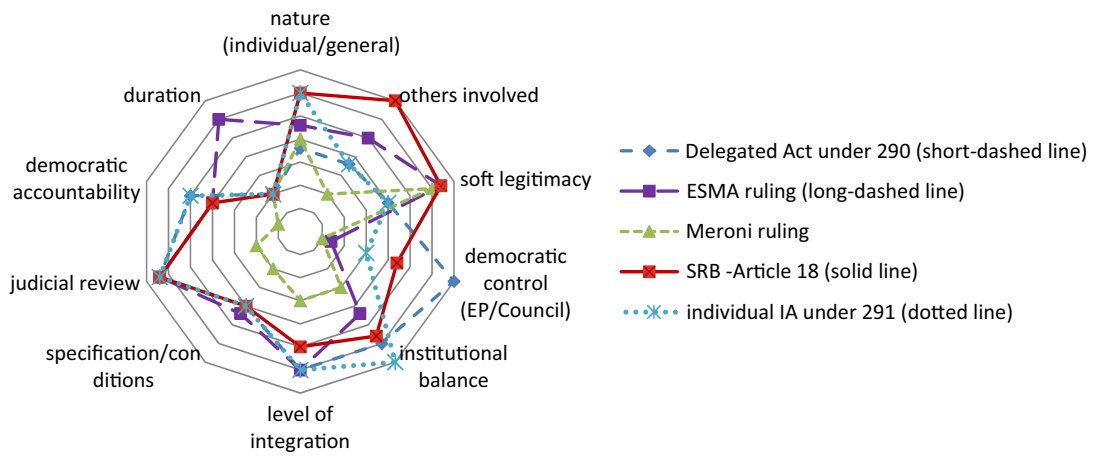

Fig. 1 Dynamic system of key parameters for assessing the legitimate scope of delegation to EU Agencies

\subsubsection{Participation of Third Countries}

Group entities in third countries are formally/legally not affected by a resolution decision of an EU authority, there is no extraterritorial effect, or automatic recognition as within the EU. Under certain circumstances also an EU branch of a group with the parent in a third country can be put into resolution by an EU RA, if the authority of the third country does not cooperate and if the EU resolution authority decides this is necessary and in the public interest. ${ }^{28}$ The resolution measures taken will in most cases impact group entities located in other jurisdictions. Third country authorities will be involved and informed to different degrees, dependent for example on whether a bilateral or multilateral framework for cooperation has been agreed ex ante (crisis management groups (CMGs) at the international level; group resolution colleges). Also cross border recognition could (theoretically) be agreed upon. Decisions on the recognition of resolution action by third country resolution authorities are made by the relevant EU resolution college. $^{29}$ In the absence of a resolution college or if the college cannot unanimously agree on a joint decision, each resolution authority concerned makes its own decision on the recognition of foreign resolution action. According to the BRRD resolution authorities may refuse recognition of non-EU resolution action on the following grounds: (i) that it would have adverse effects on financial stability of the Member State; (ii) that creditors or depositors located in an EU Member State would not receive the same treatment as the local third country creditors; or (iii) if enforcement would have material fiscal implications for the Member State or would be contrary to national law.

\footnotetext{
28 Art. 96 BRRD.

29 Arts. 94 and 95 BRRD.
} 


\subsection{Resolution Financing}

\subsubsection{Arrangements Under the BRRD}

Each Member State is in principle responsible for financing the resolution of financial institutions within its territory. The BRRD requires that relevant Member States share the cost of financing the resolution of banking groups that have subsidiaries in other Member States. In a cross-border group resolution scenario, the national financing arrangement of each institution that is part of a group must attempt to agree a financing plan for the group resolution and should contribute to the financing in accordance with such plan. Relevant authorities within the Member States concerned are required to pre-agree the scale of their contribution to a financing plan as part of the group resolution regime. The financing plan should take account of the distribution of losses within the group to apportion the concrete contributions of individual resolution funds.

It is recognized that a Member State may not be capable of raising sufficient funds to finance the resolution of an institution or institutions within its own jurisdiction, in which case relevant authorities will be able to ask to borrow funds from the authorities of another Member State or the SRF. In the actual case of taking resolution action and in case of extraordinary circumstances, the resolution authority may seek funding from 'alternative financing sources', e.g. to contract borrowings. If these are also insufficient and ex post contributions to the resolution funds are not readily available governments could, as a last resort and in very exceptional circumstances, use government stabilization tools to stabilize and/or recapitalize a bank.

\subsubsection{Arrangements in the Euro Area Under the Single Supervisory Mechanism $(S S M) / S R M$}

Within the SRM, the Single Resolution Funds was set up and is managed by the SRB. Compartmentalization of the SRF along national lines will continue until 2024 after which it will operate as a single fund. The financing of individual resolution cases within the euro area may continue to require national backstops or voluntary cooperation and support if the funds in the SRF provide insufficient. There is (currently) no direct credit line from the European Stability Mechanism (ESM) to the SRF.

\subsubsection{Participation of Third Countries}

Third country group entities will not per se be part of EU resolution schemes, as resolution decisions only apply within the jurisdiction of the EU. The BRRD does, however, allow and 'support' ex ante agreement on resolution planning if a third country authority agrees on the resolution scheme and to accept the measures therein (either ad hoc or mutual recognition agreements), including on the amount of financial contributions. This is an ideal means of facilitating cross-border 
resolution, but obviously the conclusion of financing agreements and recognition clauses depends on practical implementation and also political circumstances.

\section{Why Centralization of Resolution Decision-Making Powers with an EU Agency Is Not (Yet) Stipulated for: A Legal Analysis}

Resolution under the BRRD still relies more on consensus and cooperation than on a legally enforceable centralized resolution process (as outlined in Sect. 1). EBA mediation rights do not change this assessment. As for the core decisions of adopting a resolution scheme and applying resolution tools, only EBA assistance but no binding EBA mediation is foreseen. Also as regards the adoption of resolution plans, the fiscal impingements clause can prevent EBA mediation. Also, if no joint decision can be sought for the adoption of a group wide recovery plan, each individual national resolution authority of a subsidiary can ask for one at the individual entity level. Within the SRM, the SRB takes a centralized decision on resolution planning and the application of resolution tools. However, also under the SRM a case is (theoretically) possible where no group centralized resolution action is applied-despite an existing resolution plan adopted by the SRB-if the European Commission and Council exercise their veto rights or if there is no majority in the SRB itself. The decision-making process for the adoption of a resolution scheme finally agreed upon is simpler than versions discussed during the negotiations. Still, it remains complicated and its practical, time efficient implementation is questionable, especially in light of the involvement of the European Commission and Council. In cross-border resolution cases, third country authorities will still have to deal with different EU resolution authorities if parts of a group are not located within the SRM. This process will be facilitated by resolution colleges, who can serve as a single point of contact.

\subsection{The Legal Argument for a (Non-)Delegation of Resolution Decisions to the SRB}

Under the set-up of the Treaty on the Functioning of the European Union (TFEU) only institutions of the Union may establish the resolution policy of the Union. The Commission originally proposed that the SRB should recommend resolution action, with the resolution decision taken by the Commission. ${ }^{30}$ This was based on the assumption that Agencies are not to be empowered with matters that imply '[a] margin of discretion'. In the final text, the SRB responsibilities are substantively enhanced and the SRB is given the power to formally adopt a resolution decision. It was, however, held necessary by the legislators to involve the Commission and Council, as institutions which may exercise implementing powers, in accordance with Article 291 TFEU, to veto the resolution scheme as proposed by the SRB. The

\footnotetext{
30 Art. 12 COM 'the Commission shall decide, on its own initiative or taking into account, if any, the communication referred to in paragraph 1 or the recommendation of the Board referred to in paragraph 5, whether or not to place the entity under resolution, and on the framework of the resolution tools that shall be applied [...]'.
} 
Council-flowing out from its implementing powers-controls SRB resolution decisions for aspects which have an 'impact on financial stability' as well as on 'the fiscal sovereignty of Member States', i.e. 'public interest' and the use of the SRF. The Commission is empowered to assess 'the discretionary aspects of the resolution scheme' under Article 18, as well as for a decision on capital write down ex ante resolution. The legislators apparently assume that no (wide) 'margin of discretion', as formulated in Recital 24, is to be exercised by the SRB in the application of its other powers such as: the assessment that the conditions for entering into resolution are not met; the adoption of resolution plans including the removal of impediments to ensure an entities resolvability; the definition of MREL.

The Commissions and the EU legislators strong standing in limiting the SRBs powers during the negotiations can be traced back to their traditionally 'strict and limited' interpretation of Meroni. In preparatory legislative documents as well as in literature, it is commonly held that under the current set up of the TFEU only 'Union bodies' can be tasked with the adoption of binding acts of general nature as well as with individual (resolution) decisions involving 'a margin of discretion'. Reference is thereby made to the system established under Article 290/291 as well as to the 'Meroni ruling'. ${ }^{31}$ It appears that some national authorities, e.g. the Bundesbank in Germany, would have been in favor of delegating more autonomous powers to the SRB to ensure a more efficient SRM, but argued that such delegation would require a treaty change. ${ }^{32}$ This paper does not address any possible future treaty change to create a solid legal basis for the wider Banking Union, including for taking resolution actions by the $\mathrm{SRB}$, or even the establishment of a supervisory and/or resolution agency for the whole EU. The aim is rather to discuss whether under current institutional arrangements, from a purely legal perspective, direct autonomous empowerment to take resolution action could theoretically be attributed to a body such as the SRB. That is, to establish under which conditions and limitations the TFEU as well as European Court of Justice (ECJ) case law would justify the autonomous delegation to a European Agency (not necessarily limited to the euro area) of a decision on the application of resolution tools.

\footnotetext{
31 The Council Legal Service concludes in its opinion on SRM dated 7 October 2013 that the following delegated powers of the SRB would not comply with Meroni due to their excessively wide margin of discretion: drafting of certain aspects of the resolution plan; possibility to grant simplified obligations or waivers in relation to the drafting of the resolution plan; definition of certain aspects of the content of the resolution scheme; individual contributions; extension of the initial period for reaching the target level for the Resolution Fund; borrowing from financing arrangements within non-participating Member States or the alternative funding means; investment strategy of the Fund; use of the Fund in a resolution procedure; sanctioning powers, see: Kern Alexander, 'Bank Recovery and Resolution in Europe-The EU Bank Recovery and Resolution Directive in Context', presentation at the Symposium 'Bank Recovery and Resolution in Europe', 18-19 October 2013, slide 19. See also http://www.finanzen.net/nachricht/aktien/ EU-Juristen-skeptisch-bei-geplanter-Bankenabwicklungsbehoerde-2652319 (accessed 24 April 2017).

32 Bundesbank, 'Europe's New Recovery and Resolution Regime for Credit Institutions', monthly report, June 2014, pp. 50, 52. See also Geeroms and Karownik (2014), arguing that a Treaty change would be required for empowering another body than the Commission for taking resolution actions and criticise Councils and NRAs involvement.
} 


\subsection{The SRB: An EU Agency}

The SRM introduced the SRB as a centralized 'agency-like' formal decisionmaking body endowed with legal personality. ${ }^{33}$ The establishment of an Agency under Article 114 TFEU was upheld by the ECJ in its ENISA ruling in $2004^{34}$ and confirmed in the ESMA ruling (contrary to the opinion of the Advocate General). ${ }^{35}$ Unlike most other decision-making agencies, the SRB is not involved in the preparation of law making, i.e. it does not assist the Commission in the adoption of legal acts. Nor is it involved in the adoption of Implementing Technical Standards (ITS) or Regulatory Technical Standards (RTS) or empowered to adopt such acts itself (these powers are attributed to the European Supervisory Authorities $\left.(E S A s)^{36}\right) .{ }^{37}$ The SRB is a real 'executive' body in the sense of adopting measures of (purely) individual scope such as resolution plans and 'resolutions decisions' implemented, as a rule, by national resolution authorities.

\subsection{Justification for Empowering the SRB and Not the Commission}

Implementing powers remain, in principle, within the competence of the Member States (Art 291 first sentence), save explicit delegation by the Treaty directly (such as in the area of competition). If uniform conditions of (national) implementation are required at European level, Article 291 provides for a delegation to the

\footnotetext{
33 In Recital 31 Regulation (EU) 806/2014 SRM the Board is explicitly classified as a 'Union Agency'. Currently, apart from the SRB, nine Agencies or Agency like bodies empowered to adopt acts of binding nature exist: OHIM, CPVO, EASA, ACHA, EMA, ACER and the three ESA's.

34 Case C-217/04 UK v. Parliament and Council (ENISA) [2006] ECR I-3771. Note that the legitimate attribution of specific powers is to be assessed separately from the principle creation of an Agency. In ENISA, an indirect facilitation on the application of the harmonizing legislation sufficed. Hence, an even more direct measure - the adoption of a resolution regime by the resolution board-is to be considered as a harmonizing measure under Art. 114. See also Opinion of Advocate General in Case C-270/12 UK v. Parliament and Council (ESMA) ECLI:EU:C:2014:18; see, for the contrary, opinion that only advisory Agencies are legitimate under Art. 114: Orator (2013), pp. 852-856. See also UK argument in ESMA, para. 88, arguing that provisions empowering Agencies to adopt individual decisions would be ultra vires Art. 114

35 See ESMA, paras. 97 et seq. Only if the argument of Advocate General that the replacement of national decision-making would go beyond the limit of harmonization, as meant under Art. 114, was followed, then, for the creation of the SRB which is entrusted with direct power to address individual entities and override decisions of national resolution authorities (similar to the three ESAs), a recourse to Art. 114 would have to be considered illegitimate. In light of ECJ case law, it has to be stressed that uniform resolution tools are a pre-requisite for basing the board's powers on Art. 114. A mere centralised application of purely national resolution tools could hardly be considered as a measure for the approximation of national laws in the sense of Art. 114. See Case C-436/03 Parliament v. Council (Statute for a European Cooperative Society) [2006] ECR I-3733 (cooperative societies).

36 The three European Supervisory Authorities (ESAs) are ESMA, based in Paris, the European Banking Authority (EBA), based in London and the European Insurance and Occupational Pensions Authority (EIOPA), based in Frankfurt.

37 Only for areas in which it possesses own executive competences, the SRB is tasked with the adoption of non-binding guidelines addressed to national resolution authorities in order to ensure coherent application, e.g. the adoption of guidance on the preparation of resolution plans.
} 
Commission while stipulating for Member States control ${ }^{38}$ or, in justified specific cases, to the Council. Hence, from the mere wording of Article 291 it appears that the empowerment of Agencies with the adoption of implementing acts in what form ever (individual or general), arg. 'for implementing legally binding union acts' would be contra legem. In practice, however, EU Agencies are traditionally vested with implementing powers of individual scope, that is acts which would come under Article 291 if adopted by the Commission. As pointed out in the written observations of the Parliament in ESMA 'a conferral of such powers on Agencies has always derogated from general principles on implementation in the Treaty'. By the same token the Advocate General stresses in the ESMA ruling that 'this is a subject matter in which Agencies have long maintained an important function, and express reference in the Lisbon Treaty to its abolition would have been required to change this'. Quite on the contrary though, Agencies explicitly indirectly received a legal basis in the TFEU in the provisions on judicial review. ${ }^{39}$ What the Treaty still does not provide for is an indication of when and in what form a delegation to an agency is justified and legitimate, and which form and scope legally binding acts adopted by agencies must have (next to the system established under Articles 290/291).

In the ESMA ruling the ECJ even indicated, that the legislator is free under Article 114 TFEU in its choice of method of harmonization and 'may delegate [at its discretion] to a Union body, office or agency powers for the implementation of the harmonization sought'. ${ }^{40}$ In line with older case law on Comitology the court stresses that a delegation to agencies is particularly appropriate 'where the measures to be adopted are dependent on specific professional and technical expertise, and the ability of such a body to respond swiftly and appropriately'. ${ }^{41}$ A delegation of powers to the SRB instead of to the Commission, under Article 291, can be justified due to the special expertise and knowledge required in such a technical and economically complex field as the handling of resolution of financial institutions. The market closeness of an agency and its constituent components, i.e. the national resolution authorities established under the BRRD, adds to this argument.

\footnotetext{
38 The Comitology Regulation (EU) No. 182/2011 of the European Parliament and the Council lays down the rules and general principles concerning mechanisms for control by EU countries of the Commission's exercise of implementing powers. Interestingly, in the area of financial Services, ITS are adopted by the commission based on ESAs proposal as stipulated under Art. 15 EBA Regulation (Regulation (EU) No. 1093/2010) as lex specialis replacing a comitology procedure. In this author's view, the preparation of ITS by EBA is not to be considered as a 'mechanism for control by Member States' in the sense of Art. 291(3) because national authorities participating in EBAs Board are expressly held to not represent the interest of Member States by Art. 42 EBA Regulation. Taking this view, all ITS adopted by the Commission based on Art. 15 of ESAs regulation are at odds with the control required under Art. 291 TFEU.

39 Arts. 263 et seq. TFEU.

40 In analogy to old ECJ case law on ex-Art. 202 relating to a delegation to the Council itself, one could argue that the legislator should be held to state reasons for a delegation to an agency when it does not follow a delegation to the Commission as provided for in Art. 291.

41 ESMA, para. 105. In addition, in its White Paper 'Reforming the Commission' it is suggested to externalise Commission's activities or tasks to independent agencies in order to improve efficiency and ease the Commission's workload.
} 


\subsection{Meroni: A 1956 Court Ruling as an Argument to Prevent the Attribution of Decision-Making Powers to the SRB/an EU Resolution Agency?}

The legislative authorities argue, inter alia in Recital 24 SRMR, that no powers, including a margin of discretion, are to be delegated to the SRB. It should be noted that in principle the TFEU establishes no differentiation in scope between powers delegated to the Commission under Articles 290/291 and those delegated to an Agency. ${ }^{42}$ Such differentiation is, if at all, to be derived from the interplay of diverse constitutional principles especially the balance of power, as well as from ECJ case law. In its landmark Meroni rulings ${ }^{43}$ the Court allowed for the subdelegation to agencies ${ }^{44}$ of decision-making powers attributed by the Treaty to the High Authority (i.e. the Commission), ${ }^{45}$ but only under the following restrictive conditions:

- In application of the principle nemo plus iuris transferre potest quam ipse habet, the EC institutions cannot entrust agencies with powers they do not themselves possess. $^{46}$

- A delegation of powers should involve only 'clearly defined executive powers the exercise of which can, therefore, be subject to strict review in the light of criteria determined by the delegating authority'. ${ }^{47}$

\footnotetext{
${ }^{42}$ The TFEU explicitly presupposes the existence of legally binding acts open to judicial review in Arts. 163 et seq. TFEU.

${ }^{43}$ Cases C-9/56 and 10/56 Meroni v. High Authority [1957-1958] ECR 133.

${ }^{44}$ In the Meroni case the 'Brussels agencies' were a private body: the Joint Bureau of Ferrous Scrap Consumers and the 'Imported Ferrous Scrap Equalization Fund' as its executive organ were established under Belgium private law but entrusted under the responsibility of the High Authority with the implementation of Decision 14/55.

45 The High Authority was the executive branch of the former European Coal and Steel Community (ECSC) created in 1951 and disbanded in 1967 when it was merged into the European Commission: the Merger Treaty (or Brussels Treaty) combined the executive bodies of the European Coal and Steel Community (ECSC). It was abrogated by Art. 9(1) of the Amsterdam Treaty signed in 1997.

${ }^{46}$ Meroni C-9/56, p. 150: 'confer upon the authority receiving delegation powers different from those which the delegating authority itself received under the Treaty'. EBA mediation powers in light of Meroni might require further justification as to why ESAs mediation powers under Art 19 ESA's Regulations are compatible with the principle enshrined in Meroni that nemo plus iuris transferre potest quam ipse habet. Neither the Council nor European Parliament are attributed the competence under the TFEU to assess compliance with legally binding acts of the Union and to take binding decisions of 'judicial nature', i.e. to settle disagreements in conflict between two parties.

${ }^{47}$ Meroni distinguishes between a delegation of powers involving 'clearly defined executive powers the exercise of which can therefore be subject to strict review in the light of objective criteria determined by the delegating authority' and delegation involving 'discretionary power implying a wide margin of discretion which may according to the use which is made of it, make possible the execution of actual economic policy'. 'A delegation of the first kind cannot appreciably alter the consequences involved in the exercise of the powers concerned, whereas a delegation of the second kind, since it replaces the choices of the delegator by the choices of the delegate, brings about an actual transfer of responsibility' (Meroni C-9/56, p. 152). Despite the possible veto right of the High Authorities' representative in the Brussels Agencies pursuant to Art. 9 of Decision No. 14/55 to 'subordinate the decision to the approval of the High Authority', the delegation was considered being a 'true delegation of powers' depriving the High Authority of its final responsibility. Meroni C-9/56, p. 147.
} 
- The exercise of powers conferred upon the Agency must be subject to the same conditions to which it would have been subject if the High Authority (=the EC) had exercised them directly, i.e. duty to state reasons, duty to publish reports and data, open to review by the Court. ${ }^{48}$

- Delegation must not include such wide discretionary powers 'that enable the execution of actual economic policy', ${ }^{49}$ as this would render the principle of 'balance of powers', i.e. the 'institutional balance', ineffective. ${ }^{50}$

In Meroni, the Court held that putting into effect certain 'financial arrangements common to several undertakings' in accordance with Article 53(a) of the Treaty can in principle be delegated by the Commission to a third party. However, it contested that the delegation gave the Brussels agencies more extensive powers than those which the High Authority held, thereby infringing the Treaty by interfering with the institutional balance. It further argued that the agencies must 'exercise a wide margin of discretion as objective criteria whereby the decision of the agencies may be formulated are lacking', and that the delegated discretionary power was not considered legitimate as it would replace the 'choices of the delegator by the choices of the delegate' and would bring about an actual transfer of responsibility.

Meroni related to a very specific case of delegation of acts of a general nature in the area of competition by the Commission to a private agency. It is by no means obvious that these principles should apply when legislators have the choice to decide between a delegation to the Commission under Articles 291 or 290, or to an agency created by the legislators themselves. The 'Meroni doctrine' generalized the principles established in the special area of competition, giving the impression that beyond Meroni's sphere the Commission would also, quasi ex Treaty, possess wider implementing powers than an agency. In the following, the key criteria developed under the non-delegation Meroni doctrine, as up-held by the EU Commission, are analyzed and differences with the potential delegation of autonomous decisionmaking powers to the SRB under the current TFEU are highlighted:

- The principles developed under Meroni concerned powers delegated by the Commission to 'Brussels Agencies' set up under private law, i.e. not to a public EU body created by Union legislation such as the SRB. As agencies are nowadays explicitly (though only indirectly in the provisions on judicial review) recognized in the TFEU, it can be argued that delegation to a European entity, foreseen in treaty as a body whose acts are open to judicial review, might follow less strict rules than one to a private entity. Several Treaty provisions since

\footnotetext{
48 Meroni C-9/56, p. 149: the fact that it is possible for the Brussels agencies to take decisions which are exempted from the conditions to which they would have been subject if they had been adopted directly by the High Authority, in reality gives the Brussels agencies more extensive powers than those which the High Authority holds from the Treaty.

49 Meroni C-10/56, pp. 149/150: 'Decision No. 14/55 did not make the exercise of the powers which it conferred upon the Brussels agencies subject to any of the conditions to which it would have been subject if the High Authority had exercised them directly.' See also Meroni C-9/56, p. 175.

50 Meroni C-9/56, p. 152: 'The balance of powers [...] is characteristic of the institutional structure of the Community a fundamental guarantee granted by the Treaty in particular to the undertakings and associations of undertakings to which is applies'.
} 
Meroni acknowledge agencies power to adopt legally binding decisions with effects on third parties. This change suggests that the principles established in Romano $^{51}$ and Meroni should no longer be applied without taking into account this new institutional balance.

- Second, Meroni addressed the powers the High Authority was delegated for the adoption of 'financial arrangements' for scrap in the field of competition, an area where the Commission is directly empowered ex Treaty to adopt implementing acts. From the rule established under Meroni, that the High Authority would have had to exercise the powers itself, no general conclusion can be drawn on whether in the exercise of its implementing powers (under Article 291) the Commission would always, or only as a rule, possess powers of a wider scope than an agency. Due to its direct empowerment under Articles 101 and 102 TFEU, the Commission does not follow the procedures under Article 290/291 when taking implementing action in the area of competition. Consequently, the area of competition is traditionally excluded from the Comitology system. Following this logic, one might conclude that when acting as receiver of implementing competence under Article 291 the Commission itself is also not allowed to exercise such wide discretionary reconciliation powers as it may legitimately exercise in the area of competition (in the Meroni case). ${ }^{52}$ The Commission's possible empowerment under Articles 290/291 is dependent on the concrete circumstances of delegation and the checks and balances included, different from that of an agency and in practice (but not necessarily legally) of wider scope.

- Third, in the underlying basic act of the Meroni case, no principles were provided to the agency being guided in its reconciliation. It is clear from Meroni and Comitology case law that the 'resolution policy' is to be laid down in the basic act (the SRMR and BRRD). Old Comitology case law and Meroni both stress that the 'policy', that is, the 'general principles' or the 'essential elements' of the respective area is to be laid down in the basic act. The BRRD and Single Resolution Mechanism Regulation (SRMR) leave considerable discretion to the SRB when dealing with individual institutions allowing for flexibility and sophisticated economic assessment in the single case. A decision on resolution schemes for failing banks will (naturally) always entail a [wide] margin of discretion. Under the BRRD the resolution plan constitutes an interesting step quasi in between: the authorities' possible use of tools. Still, changing circumstances will in practice require far reaching ad hoc assessments. Hence, a certain room of maneuver and assessment to 'reconcile the many requirements of a complex and varied economic policy ${ }^{53}$ will be required $a d$ hoc at the moment of taking the resolution decision. The key question is whether the

\footnotetext{
51 Case 98/80 Romano [1981] ECR 1241.

52 In the Meroni case, however, the potential competences of the High Authority were clearly considered to be of wider scope than the ones attributed to the Brussels Agencies. The Court in Meroni held that exactly what was not considered legitimate to be decided by the Agencies because of not being sufficiently defined, i.e. relating to the assessment of 'economic facts and circumstances relevant for [taking the decisions under Article 5] could and should have been exercised by the High Authority itself.'

53 Meroni C-9/56, p. 153.
} 
criteria for applying resolution tools are sufficiently defined or whether they leave it up to the SRB to exercise unjustified and non-objective 'discretionary powers' not amenable to judicial review. From ECJ case law ESMA, the Community Plant Variety Office (CPVO) and Meroni, it can be concluded that the capacity to judge facts and circumstances and to apply general principles for the relevant case might well be delegated to agencies, as long as policy choices are made by the legislators in the empowering provision and objective criteria are provided to assess the application of these principles. Furthermore the Court in its ESMA ruling on short selling justified the delegation of 'wide' discretionary powers, even as regards the adoption of an act of general nature by an agency - thereby 'extending' and interpreting Meroni under the circumstances of the TFEU. This means that the powers delegated have to be sufficiently well defined so as to preclude political leeway and be amenable to objective (judicial) review (which, however, also holds true in a similar way for Commission's powers under Articles 290/291). Whether the system created for the adoption of the resolution scheme under the SRM (with or without veto rights from the Commission and Council) is sufficiently well defined will have to be finally decided by the ECJ. In this author's view concretization and predictability falls rather short in some of the empowering provisions, particularly in the assessment not to start resolution (the public interest test as well as in the application of the WDCC and the bail-in tool, especially the exemption from bail-in).

- Fourth, the Commission's statement - that agencies can be granted the power to take individual decisions in specific areas but cannot adopt acts of general regulatory nature ${ }^{54}$ — cannot be upheld and actually was never legally backed by Meroni. The Meroni agencies were empowered to adopt acts of a general nature, including for example defining import amounts at country level, criteria for calculating economy in scrap, and the amount of bonuses to be granted for such economies. The powers of the SRB are of individual nature. Resolution decisions apply to a single entity via instructions by the SRB to national resolution authorities. Though resolution has broad economic effects on many individuals and the society at large, the decisions of the SRB are per se 'only' applicable to the institutions concerned, i.e. an act of individual nature. In Case T-187/06 the Court accepted that an agency such as the CPVO can be entrusted with the exercise of a 'broad margin of discretion' with regard to complex botanical/chemical assessments in the individual case. There is no reason why such argumentation should, in principle, not also be valid for 'complex economic assessment'. Furthermore, the Court in its ESMA ruling on short selling justified the delegation of 'wide' discretionary powers, even with regard to the adoption of an act of general nature by an agency-thereby 'extending' and interpreting Meroni under the circumstances of the TFEU.

- Sixth, and probably most importantly, the BRRD stresses that management measures by (national) resolution authorities-within the SRM mutatis mutandis

\footnotetext{
$54 \operatorname{COM}(2008) 135$ final, Communication from the Commission to the European Parliament and the Council-European Agencies-The way forward.
} 
by the SRB - 'may require complex economic assessments and a large margin of discretion'. The BRRD explicitly justifies such wide delegation of powers to NRAs stating that those authorities are 'specifically equipped with the expertise for making those assessments and for determining the use of the margin of discretion' (open to judicial review). Against that background there is no obvious argument why national resolution authorities should legitimately be delegated such wide scope but not a central body made up of exactly these authorities (combining and multiplying their expertise).

In sum, Meroni is to be read, interpreted and also limited in relation to the area of its genesis: That is, a delegation by the Commission in the area of competition to a private body. This does not mean that the Meroni principles are no longer valid, but that they are to be applied in the context of their own establishment as well as adapted to a new constitutional order. ${ }^{55}$ From ESMA it is evident that executive powers - also of general nature-can, regardless of their 'importance', be legitimately delegated to an agency as long as they are embedded in a system of checks and balances, i.e. clearly defined for special purposes, reviewable by 'objective criteria' and not held to be of such nature as to negatively influence the institutional balance. The answer to the question on the limits of the SRBs powers is dependent 'on very close scrutiny of the powers conferred, how precisely they have been delineated, the adequacy of the checks and balances on the use of the powers, and the amenability of the arrangements to judicial review in light of the objectives of the SRM'.56

In the example of the SRB this would mean that the adoption of a resolution scheme could well be legally delegated to it alone without veto powers of the Commission and Council. Any involvement of other actors (e.g. veto rights from the Commission or Council) will extend the scope of legitimate delegation (as shown in the graph). For practical reasons a stronger involvement in resolution planning could be considered rather than in the actual case of adopting a resolution decision, when time will be key.

Table 1 shows the main criteria of a dynamic system of parameters (drawn up in conclusion from ECJ case law as well as general principles) for assessing the legitimate scope of agencies' powers:

- The nature of an act: individual acts might contain a rather wide empowerment whereas general acts might be of rather strict scope (not very large discretion).

- Specification of the delegated power: objective criteria and conditions imposed in the empowering provision ('essential elements'): the more concrete, the wider the scope of empowerment.

- Level of integration: the more integrated the regulated area, the wider the scope.

\footnotetext{
55 Also the ECJ, though generally rather reluctant to directly mention Meroni in following rulings, upheld the principles established, by referring to Meroni, as regards a case of internal conferral of power to one of the organs of the European Central Bank in Case C-301/02 P Tralli v. ECB [2005] ECR I-4071, para. 43 and in Case T-333/99 X v. ECB, para. 102 as well as Joint Cases C-154/04 and C-155/04 Natural Health [2005] ECR I-6451, and more recently in ESMA.
}

56 Ferran (2014), p. 24. 
Table 1 Overview de/centralized decision-making powers under the BRRD and SRM if no joint decision can be reached

\begin{tabular}{|c|c|c|c|c|c|}
\hline Key resolution decisions & $\begin{array}{l}\text { If NO JOINT DECISION can } \\
\text { be reached decision } \\
\text { taken by }\end{array}$ & $\begin{array}{l}\text { EBA } \\
\text { mediation }\end{array}$ & Euro area & $\begin{array}{l}\text { Involvement of non- } \\
\text { euro area EU MS }\end{array}$ & $\begin{array}{l}\text { Involvement of } 3^{\text {rd }} \\
\text { countries }\end{array}$ \\
\hline \multicolumn{6}{|l|}{ RECOVERY PLANING } \\
\hline Group recovery plan & parent supervisor $^{a}$ & $\begin{array}{l}\text { binding } \\
\text { parts) }{ }^{\mathrm{b}}\end{array}$ & ECB decision & $\begin{array}{l}\text { Information } \\
\text { cooperation (MoU of } \\
\text { ECB with non- } \\
\text { participating MS) }\end{array}$ & $\begin{array}{l}\text { Information } \\
\text { cooperation }\end{array}$ \\
\hline $\begin{array}{l}\text { Group recovery plan } \\
\text { measures at } \\
\text { level (e.g. materiary } \\
\text { deficiencies; enable } \\
\text { recapitalization, change } \\
\text { structure, funding etc.) }\end{array}$ & host supervisor(s) $^{c}$ & $\begin{array}{l}\text { Binding (for } \\
\text { parts) }\end{array}$ & ECB decision & $\begin{array}{l}\text { Information } \\
\text { cooperation } \\
\text { (MoU of ECB with } \\
\text { non-participating MS) }\end{array}$ & $\begin{array}{l}\text { Information } \\
\text { cooperation }\end{array}$ \\
\hline $\begin{array}{l}\text { Need for individual } \\
\text { entity recovery plan }\end{array}$ & host supervisor(s) ${ }^{e}$ & - & & & \\
\hline IGFSA agreement & parent supervisor $^{\top}$ & Binding & $\begin{array}{l}\text { No IGFSA (ECB } \\
\text { centralized } \\
\text { supervision) }\end{array}$ & - & $\begin{array}{l}\text { May be part of an } \\
\text { IGFSA }\end{array}$ \\
\hline IGFS actual support & $\begin{array}{l}\text { Supervisor of providing } \\
\text { entity }^{\mathrm{g}}\end{array}$ & Assistance $^{h}$ & $\begin{array}{l}\text { No IGFSA (ECB } \\
\text { centralized } \\
\text { supervision) }\end{array}$ & - & $\begin{array}{l}\text { May be part of an } \\
\text { IGFSA }\end{array}$ \\
\hline \multicolumn{6}{|l|}{ RESOLUTION PLANNING } \\
\hline Group resolution plan & $\begin{array}{l}\text { parent RA on group plan' } \\
\text { host RA(s) on subsidiary } \\
\text { plans }\end{array}$ & $\begin{array}{l}\text { Binding but } \\
\text { fiscal } \\
\text { impingement } \\
\text { clause }^{k}\end{array}$ & SRB (no veto) & $\begin{array}{l}\text { Communication to RA } \\
\text { of Subsidiaries or sig. } \\
\text { branches }\end{array}$ & $\begin{array}{l}\text { Cooperation and } \\
\text { coordination to be } \\
\text { identified in the plan }\end{array}$ \\
\hline $\begin{array}{l}\text { Group resolvability } \\
\text { assessment }\end{array}$ & $\begin{array}{l}\text { parent RA on measures at } \\
\text { group level' } \\
\text { host RA(s) on measures at } \\
\text { individual level }\end{array}$ & $\begin{array}{l}\text { Binding but } \\
\text { fiscal } \\
\text { impingement } \\
\text { clause }^{n}\end{array}$ & $\begin{array}{lr}\text { Central } & \text { SRB } \\
\text { decision } & \text { in } \\
\text { interaction } & \text { with } \\
\text { Bank } & \end{array}$ & $\begin{array}{l}\text { Report to RA of sig. } \\
\text { branches (not Sub!) }\end{array}$ & $\begin{array}{l}\text { Information } \\
\text { cooperation }\end{array}$ \\
\hline $\begin{array}{l}\text { Remove impediments to } \\
\text { resolvability for the } \\
\text { group }\end{array}$ & $\begin{array}{l}\text { parent RA on the } \\
\text { measures to be taken at } \\
\text { group level }^{\circ} \\
\text { Host RAs on measures to } \\
\text { be taken at individual } \\
\text { level }^{p}\end{array}$ & Binding & ECB & Cooperation? & \\
\hline $\begin{array}{l}\text { MREL at consolidated } \\
\text { level }\end{array}$ & parent $\mathrm{RA}^{\mathrm{q}}$ & Binding $^{r}$ & $\mathrm{ECB}$ & & $\begin{array}{l}\text { third-country } \\
\text { subsidiaries of the } \\
\text { group are to be } \\
\text { considered (i.e. if } \\
\text { resolved separately } \\
\text { according to the } \\
\text { resolution plan) } \\
\end{array}$ \\
\hline MREL at subsidiary level & host RA(s) $)^{5}$ & Binding $^{t}$ & $\mathrm{ECB}$ & & \\
\hline \multicolumn{6}{|l|}{ RESOLUTION ACTION } \\
\hline $\begin{array}{l}\text { Triggering of resolution } \\
\text { for each legal entity }\end{array}$ & $\begin{array}{ll}\text { National } & \text { Resolution } \\
\text { and/or } & \text { Supervisory } \\
\text { authority } & \\
\end{array}$ & & ECB or SRB & $\begin{array}{l}\text { Information } \\
\text { cooperation }\end{array}$ & $\begin{array}{l}\text { Information } \\
\text { cooperation }\end{array}$ \\
\hline $\begin{array}{l}\text { Resolution action for } \\
\text { parent that includes a } \\
\text { group resolution scheme }\end{array}$ & $\begin{array}{l}\text { Only for financial stability } \\
\text { reasons: host RA take } \\
\text { decision for its subsidiary } \\
\text { if no joint decision on } \\
\text { group scheme proposed } \\
\text { by parent RA }\end{array}$ & Assistance & $\begin{array}{l}\text { SRB - } \\
\text { Commission and } \\
\text { Council Veto }\end{array}$ & $\begin{array}{l}\text { Information } \\
\text { cooperation }\end{array}$ & $\begin{array}{l}\text { Information } \\
\text { cooperation }\end{array}$ \\
\hline $\begin{array}{l}\text { Resolution action for } \\
\text { subsidiary and the action } \\
\text { likely triggers the } \\
\text { resolution of other } \\
\text { group members }\end{array}$ & $\begin{array}{l}\text { (for financial stability } \\
\text { reasons): Own decision of } \\
\text { host RA if no joint } \\
\text { decision on group scheme } \\
\text { proposed by parent RA }\end{array}$ & Assistance & $\begin{array}{l}\text { SRB - } \\
\text { Commission and } \\
\text { Council Veto }\end{array}$ & $\begin{array}{l}\text { Information } \\
\text { cooperation }\end{array}$ & $\begin{array}{l}\text { Information } \\
\text { cooperation }\end{array}$ \\
\hline Bail-in & $\begin{array}{l}\text { Automatic recognition } \\
\text { within EU }\end{array}$ & & $\begin{array}{l}\text { Automatic } \\
\text { recognition } \\
\text { within EU }\end{array}$ & $\begin{array}{l}\text { Automatic recognition } \\
\text { within EU }\end{array}$ & recognition clause \\
\hline
\end{tabular}


Table 1 continued

aArt. 8(3) BRRD

${ }^{\mathrm{b}}$ Only on measures to direct the institution to reduce risk profile, enable recapitalization, changes to funding strategy Art. 8(7) BRRD

${ }^{\mathrm{c}}$ Art. 8(4) BRRD

${ }^{\mathrm{d}}$ Only on measures to direct the institution to reduce risk profile, enable recapitalization, changes to funding strategy Art. 8(7) BRRD

eArt. 8(4) BRRD

${ }^{\mathrm{f}}$ In addition, shareholder agreement is required, Art. 20 BRRD

${ }^{\mathrm{g}}$ Art. 25 BRRD

${ }^{\mathrm{h}}$ If the supervisor of the receiving entity objects to a limitation, Art. 25

${ }^{\mathrm{i}}$ Art. 13(5)

${ }^{\mathrm{j}}$ Art. 13(6)

${ }^{\mathrm{k}}$ Art. 13(9)

${ }^{1}$ Arts. $13(5)$ and $16(3)$

${ }^{\mathrm{m}}$ Arts. 13(6) and 16(3)

${ }^{\mathrm{n}}$ Arts. 13(9) and 16(3)

${ }^{\circ}$ Report from group RA and consolidating supervisor and EBA to parent bank and RAs of subsidiaries; Art. 18(6) BRRD

${ }^{\mathrm{p}}$ Art. 18(7) BRRD

${ }^{\mathrm{q}}$ Joint decision drafted by group RA, Art. 45(9)BRRD; Parent RA sets MREL at parent level, may be waived Art. 45(11) BRRD

${ }^{\mathrm{r}}$ Art. 45(9) BRRD

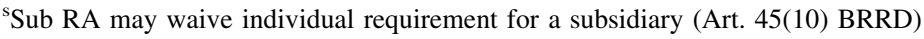

${ }^{\mathrm{t}}$ Art. $45(10)$

uArt. 92(3)/(4) BRRD; if the parent enter into resolution without triggering effects on the group: simple decision by the parent RA

${ }^{\mathrm{v}}$ If resolution action for subsidiary does not trigger resolution of other group entities simple decision of host RA. If resolution of other is triggered: Joint decision on group resolution scheme proposed by parent RA

- Democratic legitimacy: Control by EP and/or Council, i.e. via veto powers as under Article 290.

- Soft/Out-put legitimacy: knowledge, expertise, closeness to the market.

- Involvement of other institutions and/or experts: consultation of scientific committees, other public bodies or stakeholders, including binding Member States control powers as under Comitology in the case of Article 291 (contribution to output-legitimacy but also direct democratic element and/or minimising the effect on the institutional balance)

The simple conclusion that a less important implementing act might have a wider scope and require a less specific empowering basis is always to be seen-and weighted-in relation to the control provided for. Hence no clear definition but a system depending on the scope/importance (content)/control/level of integration (field) is to be established. The Commissions possible empowerment under Articles $290 / 291$ is depending on the concrete system of checks and balances foreseen, 
different from that of an Agency and in practice (but not necessarily legally) of wider nature. If however, Member States 'control' as provided for by Article 291 is limited to mere advise as is the case under the Comitology advisory procedure, shown in the dotted line, the Commissions scope of delegation will be of rather limited nature (assuming similar conditions, scope and content of the matter to be decided), or even in the case of a delegated act for which no control by EP and Council is foreseen (note that the short dashed line assumes a delegated act for which strong control and veto powers of EP and Council are stipulated and therefore a wide scope). ${ }^{57}$

As shown on the solid line, the system established under the SRM for the adoption of the resolution scheme (Article 18) allows a rather wide scope of empowerment (similar to ESMA (long dashed line), though for different reasons). Irrespective of whether it is legally required and/or political justified, the Commission's and Council's involvement in the adoption of the resolution scheme enlarges the possible scope of delegation. It is, however, not evident to which additional aspects the Commission's veto power actually adds, except for obvious control (extending the scope of delegation to the maximum under the criterion 'others involved'), which, however, would also hold true for other bodies involved. Clearly, the effect on the institutional balance is minimised by the Commissions and councils veto powers, though it is not evident that otherwise, if it were not an Agency, that the Commission would have been delegated direct resolution power (as a quasi-ministerial body without Member States involvement as is ensured under the SRB). Also, it can hardly be expected that the Commission would add additional technical or economic expertise in relation to the SRB experts, including their access to expertise from the national markets. In view of enhancing direct democratic legitimacy, the additional input of the Commission appears rather marginal, as the chair of the SRB is to be approved by the European Parliament anyway and the commission itself does not possess direct legitimacy from the electorate. ${ }^{58}$ In addition, the SRB is attributed bottom-up legitimacy from its constituent parts the NRAs.

Figure 1 shows that the scope of delegation can legitimately be of a wider nature if certain checks and balances are provided for, which did not (yet) exist in the Meroni case. It follows from such dynamic assessment that the adoption of a resolution scheme under Article 18 SRM Regulation, without Commission and Council veto rights might well be considered legitimate from a purely legal point of view, if respective checks and balances are stipulated. No treaty provision including Articles 290/291, nor ECJ rulings justify the non-delegation doctrine of delegating the adoption of individual resolution schemes to an EU Agency. Assuming the allowance of a less wider scope under the parameter 'others involved', i.e.

\footnotetext{
57 Also under Art. 290 control by EP and Council is not obligatory but depends on the legislator's discretion in each single case. Note that part of literature as well as the Advocate General in ESMA argues that measures of Art. 290, i.e. of general nature cannot be delegated to an Agency. This is however, contrary to Joint Cases C-154/04 and C-155/04 Natural

Health [2005] ECR I-6451, para. 90 and also to Meroni.

58 Art. 56 Regulation (EU) 806/2014. As regards the dismissal of the vice/Chair, the EPs powers under para. 9 might still be strengthened.
} 
abolishing the Commissions (and Councils) veto powers, a similar scope could well be delegated to the SRB autonomously, if other elements like a more specific delineation and specification of the powers delegated, stronger accountability and EP scrutiny or a limitation in time, would be foreseen to broaden the possible scope of empowerment.

The different lines show the 'circle' of delegation: the bigger the circle, the wider scope of empowerment is justified; Fig. 1 does not take into account the different (legal) weights of the criteria assessed.

\section{Conclusions}

The new European framework promotes cross-border cooperation and informationsharing. However, when it comes to the adoption of a cross-border recovery plan, the provision of IGFSAs or a banking group's cross-border resolution plan or resolution strategy, there is no legal certainty that future cross-border cases will be managed and coordinated under a joint approach and in a consistent manner within the EU. For example, although the European Banking Authority (EBA) is empowered to act as a binding mediator concerning the adoption of a group resolution plan, national authorities can impede its mediation by invoking the 'fiscal impingement' clause declaring that certain aspects of the group resolution plan would impinge on a Member States fiscal responsibilities. Also, when it comes to the key decision to adopt a group resolution strategy in cases where more than one entity of a group within the EU is considered to be failing or likely to fail, the EBA can only facilitate a joint decision but does not exercise binding mediation powers. In the implementation of the resolution tools, one of the key challenges will be the effective transposition of the BRRD into national laws. In particular, differences in the application of moratoria or in insolvency regulations (subordination) may increase the asymmetry among countries and even affect the calculation of the NCWOL test (thereby limiting the extent to which the bail-in instrument may be applied). Moreover, the limited legal certainty of non-binding agreements could create a 'false sense of security' by relying on ex ante reached understandings (like a group cross-jurisdictional resolution plan), which in the case of need (i.e. the application of a resolution scheme) could be deviated from by individual authorities. This is different under the SRM where the SRB possesses centralized power to apply resolution tools to all entities under its remit; though this power is limited by the veto powers exercisable by the Commission and the Council.

Within the EU the national resolution authorities and the SRB are held to communicate their plans, decisions and/or measures within colleges, in principle open also for third countries (as observers). While this is a positive step forward it is not so clear in all cases what this means for host countries. It will not always be easy to balance different interests and mandates in colleges and find a common position. Even within the EU, situations can arise where national resolution authorities in the non-participating Member States are left with limited information and might look to ensure their own interests and adopt their own national recovery or resolution plans for their subsidiaries, and take ring fencing measures. The final decision on key 
policy issues especially when it comes to burden sharing, is still taken at national level. Also under the SRM the public backstop will ultimately be a national in case of failure of EU cross border bank.

Regarding cooperation with third countries, major improvements have been made and formalized frameworks created, via CMGs for G-SIFIS and Colleges for the EU. However, it seems too early to assess if and how cross-border arrangements will be implemented in practice and information shared or even recognition of resolution action be agreed. Cross-border cooperation and recognition of foreign resolution actions will be crucial to the success of resolution regimes. Introduction of a special resolution authority specifically dealing with a gone concern bank will facilitate cross-border cooperation, as responsibilities are more clearly defined between resolution and supervision, but will also require the involvement of more actors (supervisory and resolution authorities), which make cooperation and coordination more challenging. For third countries, the SRB acts as a single point of contact representing all the RAs of the participating (i.e. euro area) Member States. Third countries must (pro-actively) establish and maintain bilateral cooperation and coordination arrangements to ensure their involvement during resolution planning and when taking resolution action. The creation of an EU-wide resolution agency would clearly facilitate cooperation and reduce the risk of 'going it alone'.

From a purely legal point of view, there are no principle impediments to the empowerment of the SRB as a 'fully autonomous' resolution authority, including the power to decide autonomously on the application of individual resolution schemes. The legal requirement for Commission and Council to have veto powers in the adoption of a resolution scheme as an outflow of its powers under Article 291, is not evident from the TFEU nor from ECJ case law. Depending on the intensity of checks and balances, as well as the specifications of the empowering provisions, the adoption of the resolution scheme could, from a legal point of view, in principle be attributed to the SRB or any other EU Agency competent for the whole EU, without Commission and Council veto powers. Any involvement of other actors, however, will extend the scope of legitimate delegation. For practical reasons, a stronger involvement of other actors during resolution planning could be considered, rather than at the time a resolution decision is required when speed is essential. Political interests will also no doubt be a relevant factor when it comes to the delegation of bank resolution powers to an EU centralized agency, especially as long as burden sharing will ultimately be depended on national lines nd no EU public backstop agreed upon. The idea of a fully centralized (and arguably more efficient) decisionmaking body might trigger political 'reluctance to disrupt deep-rooted interdependencies between national politics and finance'. 59

Open Access This article is distributed under the terms of the Creative Commons Attribution 4.0 International License (http://creativecommons.org/licenses/by/4.0/), which permits unrestricted use, distribution, and reproduction in any medium, provided you give appropriate credit to the original author(s) and the source, provide a link to the Creative Commons license, and indicate if changes were made.

59 See Piris (2012). 


\section{References}

Alford D (2013) International financial reforms: capital standards, resolution regimes, and supervisory colleges and their effect on emerging markets. In: Masahiro K, Prasad ES (eds) New paradigms for financial regulation: emerging markets perspectives. Brookings Institution Press, Washington, DC, pp 244-278

Chiti E (2015) In the aftermath of the crisis - the EU administrative system between impediments and momentum. Camb Yearb Eur Leg Stud 17:311-333

Ferran E (2014) European Banking Union: imperfect, but it can work. University of Cambridge Faculty of Law Research Paper No 30/2014

Geeroms H, Karownik P (2014) A Banking Union for an unfinished EMU. Policy Brief, Martens Centre, May 2014. https://www.martenscentre.eu/sites/default/files/publication-files/european-bankingunion.pdf. Accessed 24 July 2014

Orator A (2013) Die unionsrechtliche Zulässigkeit von Eingriffsbefugnissen der ESMA im Bereich von Leerverkäufen. Europäische Zeitschrift für Wirtschaftsrecht 24:852-856

Piris J-C (2012) The future of Europe: towards a two-speed EU?. Cambridge University Press, Cambridge 